\title{
RPP40 Gene
}

National Cancer Institute

\section{Source}

National Cancer Institute. RPP40 Gene. NCI Thesaurus. Code C104723.

This gene is involved in tRNA metabolism. 